\title{
RANCANG BANGUN GENERATOR TURBIN ANGIN PUTARAN RENDAH SEBAGAI PEMBANGKIT ENERGI LISTRIK ALTERNATIF DI DAERAH PESISIR
}

\author{
Sagita Rochman ${ }^{1)}$,Budi Prijo Sembodo ${ }^{2)}$ \\ ${ }^{1}$ Prodi Teknik Elektro, Fakultas Teknologi Industri,Universitas PGRI Adi Buana Surabaya \\ email: sagita@unipasby.ac.id \\ ${ }^{2}$ Prodi Teknik Elektro, Fakultas Teknologi Industri, Universitas PGRI Adi Buana Surabaya \\ email: budi@unipasby.ac.id
}

\begin{abstract}
Axial Flux Permanent Magnet Generator (AFPMG) of wind turbine generator has been successfully designed and fabricated. The generator has been designed for wind speed in the range of 2-6 $\mathrm{m} / \mathrm{s}$ and low rotation. The main purpose of study was to design and analyze wind turbine generator with the low speed of wind that can be generated electric power for household. The results showed that the prototype of wind turbine can be generated voltage around 22.5 $157.1 \mathrm{~V}$ with the rotation of the rotor shaft at $150-1000 \mathrm{rpm}$. Meanwhile, the prototype can be generated output power of 98.5 Watt shaft rotation of $1000 \mathrm{rpm}$ when its connected to load. Both current and voltage can be achieved around $151.4 \mathrm{~V}$ and $0.651 \mathrm{~A}$, respectively. The prototype was then conneted with DC to DC converter and DC to AC converter to generate output power of 500 $W$.
\end{abstract}

Keyword: Wind Turbine Generator, Axial Flux Permanent Magnet Generator (AFPMG)

\section{PENDAhUluan}

Tingginya kebutuhan energi menuntut untuk menciptakan berbagai alternatif energi guna memenuhinya. Pemanfaatan terhadap sumber daya alam yang terbarukan merupakan hal-hal yang harus dan terus dikembangkan agar tidak terjadi krisis dan kelangkaan energi, khususnya untuk pemenuhan kebutuhan masyarakat kepulauan. Data komprehensif potensi kincir angin di Indonesia salah satunya mengacu pada "Energy Outlook \& Statistics", Universitas Indonesia (Dalimi, 2001).

Kincir angin merupakan salah satu alternatif potensial memenuhi kebutuhan tersebut, khususnya didaerah-daerah kepulauan dengan potensi angin yang tersedia terus-menerus. Kincir angin ini menggunakan tenaga angin yang dikonversi menjadi energi listrik. Faktor utama yang mempengaruhi besarnya energi listrik yang dihasilkan berada pada ketersediaan dan kecepatan angin serta generator listrik pada kincir angin tersebut (Dipl. Kulturwirt, 2002).

Beberapa jenis generator yang digunakan adalah sikat DC, induksi AC dan generator magnet permanen. Secara tradisional, generator induksi banyak digunakan di sebagian besar aplikasi tenaga angin karena kesederhanaan mereka, fleksibilitas tinggi dan relatif rendah operasi dan biaya pemeliharaan. Generator induksi, bagaimanapun, memiliki keterbatasan utama karena mereka tidak bisa menghasilkan daya reaktif, pada kenyataannya, mereka mengkonsumsi daya reaktif. Daya reaktif ini biasanya tersedia secara eksternal melalui kapasitorterhubung di terminal generator (Daryanto, 2007).

Generator AC yang menggunakan magnet permanen untuk bidang eksitasi menawarkan sejumlah karakteristik kinerja yang unggul dibandingkan dengan ekivalen generator ac dan dc. Hal-hal yang ditawarkan dari generator $\mathrm{AC}$ adalah termasuk mengurangi volume motorkarena tidak adanya lilitan digunakan untuk bidang 
eksitasi rotor, efisiensi yang lebih tinggi karena mengurangi kerugian rotor tembaga, keandalan yang lebih baik karena tidak adanya sikat dan slip ring, faktor daya yang lebih tinggi yang bisa mendekati 1 . Turbin angin menggunakan magnet permanen umumnya jatuh ke dalam kategori mikroturbin (kurang dari $1 \mathrm{~kW}$ ), dan turbin kecil (dari $10 \mathrm{~kW}$ ke $100 \mathrm{~kW}$ ) karena keterbatasan ukuran saat pembuatan di pabrik dan kesulitan membuat potongan magnet yang besar (Daryanto, 2007).

Dengan kondisi angin di Indonesia yang mempunyai kecepatan 2-6 m/s, maka diperlukan generator yang sesuai untuk kondisi angin tersebut. Generator yang ideal adalah mempunyai karakter kerja putaran rendah. Yakni pada putaran poros rotor $300-$ 1000 rpm maka generator dapat bekerja mengeluarkan tegangan.

Di Indonesia masih cukup banyak masyarakat yang belum menikmati listrik. Ada beberapa wilayah telah menikmati listrik dengan menggunakan diesel/genset sebagai pembangkit. Dengan potensi angin yang dapat digunakan sebagai alternatif energi yang bersifat terbarukan tentu saja tidak semua wilayah. (Dalimi, 2001)

Kincir angin merupakan sebuah alat yang digunakan dalam sistem konversi energi angin (SKEA). Kincir angin berfungsi merubah energi kinetik angin menjadi energi mekanik berupa putaran poros. Putaran poros tersebut kemudian digunakan untuk beberapa hal sesuai dengan kebutuhan seperti memutar dinamo atau generator untuk menghasilkan listrik atau menggerakkan pompa untuk pengairan.

Daya (Power) Kincir angin menggunakan persamaan:

$P=1 / 2 C p \rho A v^{3}$

dengan :

$P \quad=$ Power output $(\mathrm{W})$

$C p=$ Maximum power coefficient $(0.25$ $0.45)$

$\rho \quad=$ Air density $\left(\mathrm{kg} / \mathrm{m}^{3}\right)$

$A \quad=$ Rotor swept area $\left(\mathrm{m}^{2}\right)$

$v \quad=$ Wind speed $(\mathrm{m} / \mathrm{s})$

Untuk mengoptimalkan kerja kincir angin maka peletakan pada jarak ketinggian akan memberikan pengaruh seperti Gambar 1.

Tip speed ratio (rasio kecepatan ujung) adalah rasio ujung rotor terhadap kecepatan angin bebas. Untuk kecepatan angin nominal yang tertentu, tip speed ratio akan berpengaruh pada kecepatan rotor. Kincir angin tipe lift akan memiliki speed ratio yang lebih besar dibandingkan dengan turbin tipe drag. Besarnya tip speed ratio dapat dihitung dengan persamaan :

$$
\lambda=\frac{\pi D n}{60 v}
$$

\begin{tabular}{|c|c|}
\hline$\lambda$ & $=$ Tip Speed Ratio \\
\hline$D$ & $=$ Diameter rotor $(\mathrm{m})$ \\
\hline$n$ & $=$ Putaran rotor $(\mathrm{m} / \mathrm{s})$ \\
\hline$v$ & $=$ kecepatan angin $(\mathrm{m}$ \\
\hline
\end{tabular}

dengan:

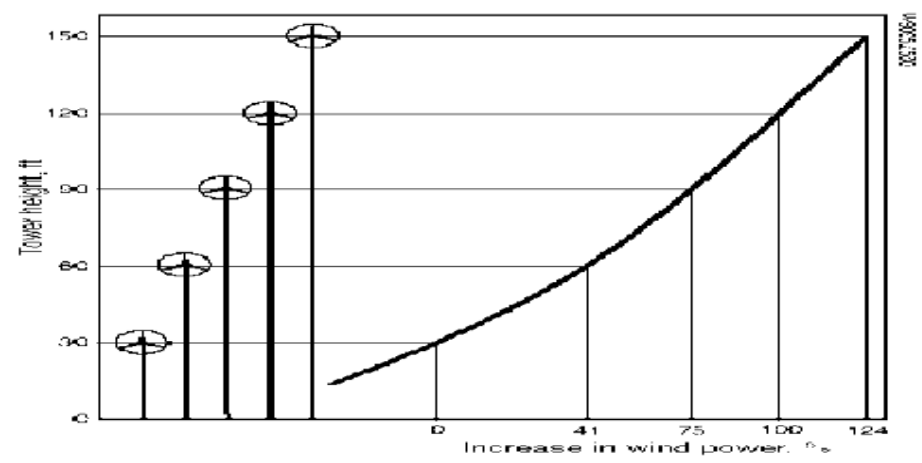

Gambar 1. Profil Kecepatan Angin terhadap Ketinggian (Erich Hau, 2005) 


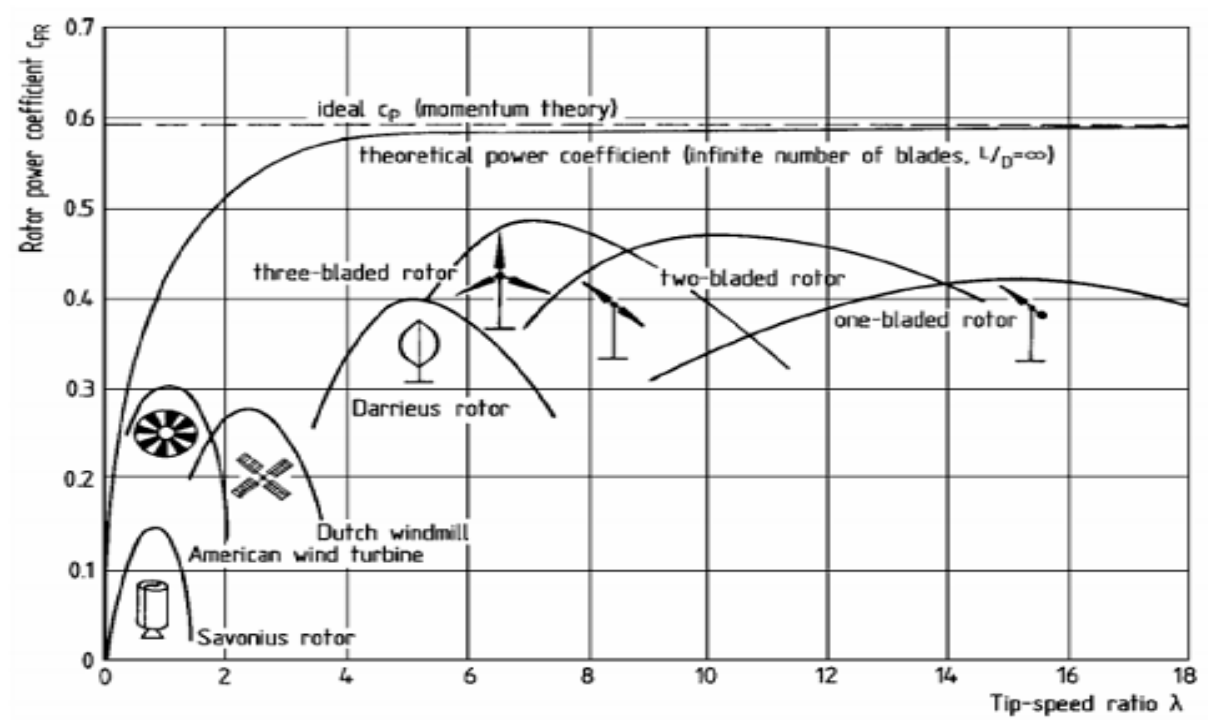

Gambar 2. Nilai koefisien daya dan tip speed ratiountuk berbagai turbin (Gustave Paul Corten,1968)

Pada Gambar 2, menunjukkan variasi nilai tip speed ratio dan koefisien daya untuk berbagai macam kincir angin.

Berdasarkan bentuk rotor, kincir angin dibagi menjadi dua tipe, yaitu kincir angin sumbu mendatar (horizontal axis wind turbine) dan kincir angin sumbu vertikal (vertical axis wind turbine) (Daryanto, 2007).

\section{Horizontal Axis Wind Turbine (HAWT) \\ Merupakan turbin yang poros} utamanya berputar menyesuaikan arah angin. Agar rotor dapat berputar dengan baik, arah angin harus sejajar dengan poros turbin dan tegak lurus terhadap arah putaran rotor. Biasanya turbin jenis ini memiliki bladeberbentuk airfoil seperti bentuk sayap pada pesawat. Pada turbin ini, putaran rotor terjadi karena adanya gaya lift (gaya angkat) pada blade yang ditimbulkan oleh aliran angin. Turbin ini cocok digunakan pada tipe angin sedang dan tinggi, dan banyak digunakan sebagai pembangkit listrik skala besar.

Jumlah blade pada HAWT bervariasi, mulai dari satu blade, dua blade, tiga blade, dan banyak blade (multi blade) yang penggunaannya disesuaikan dengan kebutuhan dan kondisi angin. Secara umum semakin banyak jumlah blade, semakin tinggi putaran turbin.

Setiap desain rotor mempunyai kelebihan dan kekurangan. Kelebihan turbin jenis ini, yaitu memiliki efisiensi yang tinggi, dan cut-in wind speed rendah. Kekurangannya, yaitu turbin jenis ini memiliki desain yang lebih rumit karena rotor hanya dapat menangkap angin dari satu arah sehingga dibutuhkan pengarah angin, selain itu penempatan dinamo atau generator berada di atas tower sehingga menambah beban tower.

\section{Vertical Axis Wind Turbine (VAWT)}

Merupakan kincir angin sumbu tegak yang gerakan poros dan rotor sejajar dengan arah angin, sehingga rotor dapat berputar pada semua arah angin. Kecepatan angin di bagian bawah sangat rendah sehingga apabila tidak memakai tower akan menghasilkan putaran yang rendah, dan efisiensi lebih rendah dibandingkan HAWT.

Generator magnet pemanen merupakan generator sinkron yang medan eksitasi dihasilkan oleh magnet permanen bukan gulungan sehingga fluks magnetik dihasilkan oleh medan magnet permanen sehingga tidak memerlukan arus eksitasi DC. Dalam struktur 
aliran fluksnya, generator magnet permanen memiliki 2 tipe, yaitu tipe aksial (Axial Fluks Permanent Magnet Generator) dan tipe radial (Radial Fluks Permanent Magnet Generator).

Axial Fluks Permanent Generator Magnet (AFPMG) merupakan generator magnet permanen yang memiliki arah medan fluks sejajar dengan sumbu putar. Fluks tersebut merupakan hasil dari gaya tarik menarik antara dua buah magnet permanen yang memiliki kutub yang berbeda.

Penggunaan dua buah magnet yang terletak diantara dua buah slot disk rotor sehingga bahan stator merupakan bahan nonmagnetik. Axial Fluks Permanent MagnetGenerator memiliki sejumlah keunggulan yang berbeda dari radial-fluks, yaitu dapat dirancang untuk memiliki rasio daya tinggi, berkurangnya rasio bahan inti

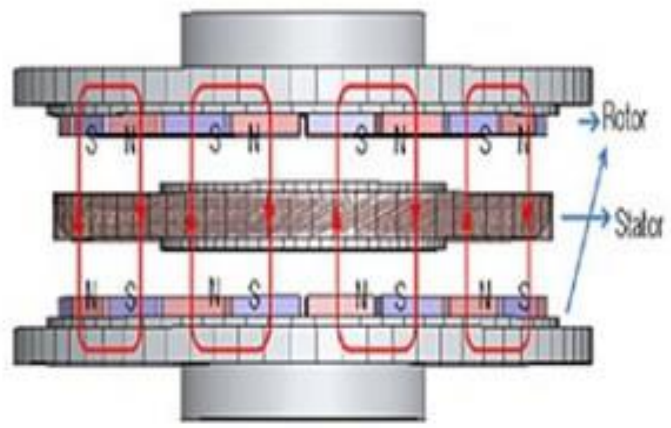

a) Aksial Fluks stator, mudah disesuaikan dengan kondisi udara, berkurangnya kebisingan dan tingkat getaran. Selain itu, arah jalan fluks di celah udara dapat bervariasi, sehingga mengurangi topologi tambahan (Adrian Augustin dkk, 2014).

Radial Fluks Permanent Magnet Generator (RFPMG) merupakan generator magnet permanen yang memiliki arah fluks radial terhadap sumbu putar sehingga arah fluks searah dengan arah putaran rotor, hal ini dikarenakan fluks dihasilkan oleh magnet magnetik inner-rotor yang letaknya melingkari lilitan bagian luar, sedangkan lilitan terdapat inti dalam yang terhubung pusat rotor. Radial Fluks Permanent Magnet Generator $(R F P M G)$ ini memiliki keunggulan yaitu mudah dalam pemasangan magnet permanen ke inner - rotor (Adrian Augustin dkk, 2014).

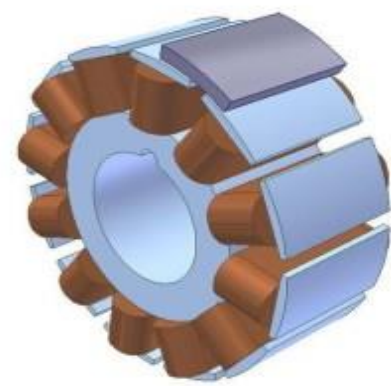

b) Radial Fluks

Gambar 3. Tipe generator magnetpermanen(Adrian Augustin dkk, 2014)

Konfigurasi tipe AFPMG, dengan piringan jenis geometri lebih mudah untuk mengintegrasikan ke dalam turbin angin yang dirancang untuk aplikasi kecepatan rendah, dibandingkan dengan tipe fluks radial. Sebuah generator AFPMG menggunakan kekuatan magnet permanen untuk menciptakan medan magnet pada rotor. Karena tidak ada arus listrik yang mengalir ke rotor, maka tidak ada kebutuhan untuk sikat, sehingga dapat meningkatkan kehandalan. Selain itu, AFPMG dapat beroperasi pada kecepatan putaran yang berbeda, sehingga produsen dapat merancang sistem transmisi turbin angin di sekitar topologi yang mereka inginkan, mungkin menggunakan satu atau dua tahap gearboks untuk kecepatan menengah, atau bahkan menghapus gearboks sama sekali untuk lebih meningkatkan kehandalan. Konsep elektromagnetik dari AFPMG tanpa inti besi stator adalah mirip dengan generator fluks radial, tetapi kurangnya inti besi menghilangkan gaya tarik menarik antara rotor dan stator. Tidak adanya kekuatankekuatan ini mengurangi beban struktural pada generator, sehingga penghematan berat material dapat direalisasikan, bahkan pada tingkat daya generator yang lebih tinggi. Dengan menghilangkan kerugian pada inti besi stator, maka AFPMG tanpa inti stator dapat beroperasi pada efisiensi yang lebih 
tinggi daripada mesin konvensional (Dae- Won Chung dkk, 2014).

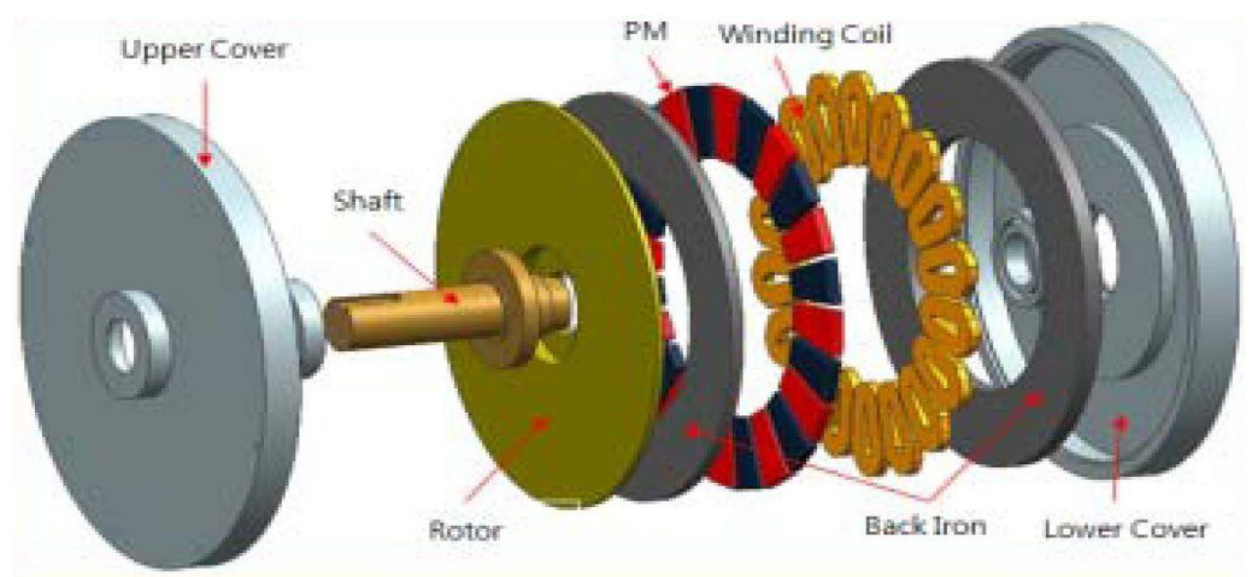

Gambar 4. Contoh struktur dasar AFPMG tanpa inti stator (Dae-Won Chung dkk, 2014)

Fluks magnetik mengalir tegak lurus melewati celah udara antara stator dan rotor. Fluks total yang melewati area permukaan magnet yang sama tidak berubah dan kerapatan fluks di celah udara adalah konstan pada arah radial.

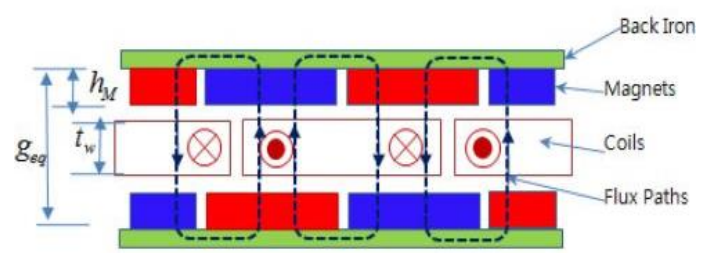

Gambar 5. Geometris dan alur fluks pada celah udara (Dae-Won Chung dkk, 2014)

Fluks magnet yang dibangkitkan oleh magnet permanen per kutub (F. J. Gieras dan kawan, 2008) adalah:

$$
\begin{aligned}
\Phi_{f} & =\int_{R_{\text {in }}}^{R_{\text {out }}} \alpha_{i} B_{m g} \frac{2 \pi}{2 p} r d r=\alpha_{i} B_{m g} \frac{\pi}{2 p}\left(R_{o}^{2}-R_{i}^{2}\right) \\
& =\alpha_{i} B_{m g} \frac{\pi}{8 p} D_{o}^{2}\left(1-k_{d}^{2}\right)
\end{aligned}
$$

dengan:

$\Phi_{f}$ : fluks magnetik (Wb)

$\alpha_{i}$ : rasio densitas fluks rata rata $B_{\text {avg }}$ ke nilai puncak $B_{m g}$ pada celah udara

$p$ : jumlah pasang kutub

$\begin{array}{lllll}R_{i}=0,5 D_{i} & : & \text { jari-jari } & \text { dalam } & \text { magnet } \\ \text { permanen }(\mathrm{m}) & & & & \\ R_{o}=0,5 D_{o} & : & \text { jari-jari } & \text { luar } & \text { magnet } \\ \text { permanen (m) } & & & & \end{array}$

$k_{d}=R_{i} / R_{o}=D_{i} / D_{o}:$ rasio diameter masingmasing magnet permanen

$D_{i} \quad$ : diameter dalam pada rotor (m)

$D_{o} \quad$ : diameter luar pada rotor (m)

Ekivalensi celah udara dari AFPMG tanpa inti stator pada Gambar 5, dinyatakan dengan persamaan (F. J. Gieras dan kawan, 2008):

$$
g_{\text {eq }}=2\left(g+0.5 t_{w}+\frac{h_{M}}{\mu_{\text {rrec }}}\right)
$$

dengan:

$g_{\text {eq }} \quad:$ kerapatan celah udara $(\mathrm{m})$

$t_{w} \quad:$ ketebalan aksial koil stator (m)

$h_{M} \quad$ : tinggi aksial magnet permanen (m)

$\mu_{\text {rrec }} \quad$ : relative recoil permeability magnet permanen 


\section{METODEPENELITIAN}

Penelitian yang dilakukan adalah penelitian pengembangan yang bertujuan untuk menemukan dan mengembangkan prototype baru atau sudah ada dalam rangka penyempurnaan dan pengembangan sehingga diperoleh hasil yang lebih produktif, praktis, efektif dan efisien (Benny Kurniawan, 2012 "Metodologi Penelitian" Cetakan Pertama, Jelajah Nusa, Bandung).

Desain generator menggunakan perangkat lunak Magnet, kemudian dilakukan fabrikasi dan pengujian serta pengambilan data yang selanjutnya dianalisis.

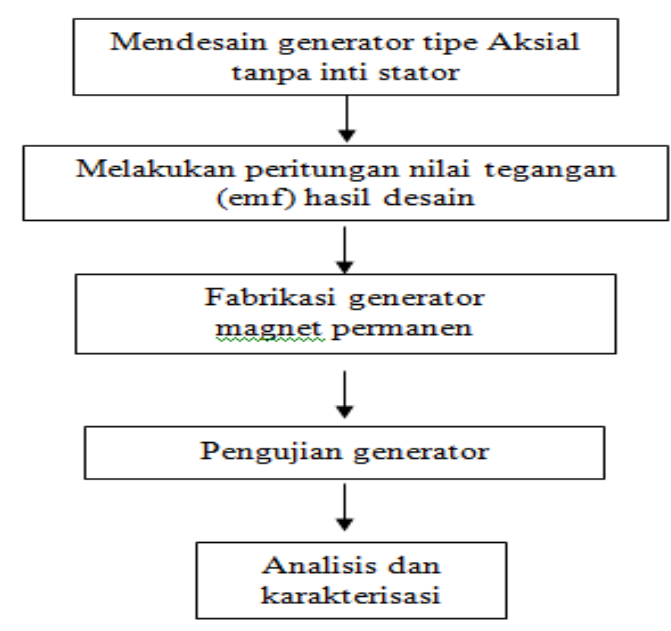

Gambar 6.Skema Tahapan Penelitian

\section{Pembuatan generator}

Desain generator yang akan dibuat adalah tipe AFPMG dengan stator tanpa inti. Rancangan desain terlebih dahulu digambar diperangkat lunak Magnet.
Kemudian disimulasikan untuk mengetahui karakteristik generator yang dihasilkan. Desain dari generator adalah sebagai berikut:

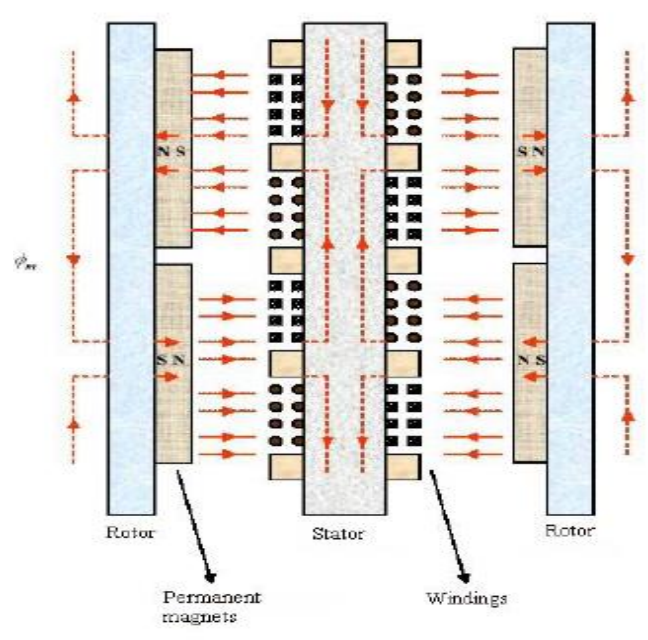

Gambar7.Desain generator tipe AFPMG tanpa inti stator 
Parameter dari generator yang akan dibuat adalah:

\begin{tabular}{|c|l|c|c|}
\hline Items & \multicolumn{1}{|c|}{ Parameter } & Unit & Nilai \\
\hline Stator & Celah udara & $\mathrm{mm}$ & 1,0 \\
& Jumlah & buah & 18 \\
& gulungan & $\mathrm{mm}$ & 350 \\
& Diameter luar & $\mathrm{mm}$ & 250 \\
& Diameter dalam & lilit & 120 \\
& Koil pada tiap & & \\
& gulungan & & \\
\hline Rotor & Jumlah magnet & $\mathrm{buah}$ & 24 \\
& Diameter luar & $\mathrm{mm}$ & 300 \\
& Diameter dalam & $\mathrm{mm}$ & 275 \\
& Kecepatan rotor & $\mathrm{rpm}$ & 300 \\
\hline Umum & Tegangan & $\mathrm{V}$ & 150 \\
& Frekuensi & $\mathrm{Hz}$ & 120 \\
& Fasa & - & 3 \\
& Daya output & $\mathrm{W}$ & 200 \\
& Area kecepatan & $\mathrm{rpm}$ & $200-$ \\
& & & 800 \\
\hline
\end{tabular}

\section{Pembuatan generator}

Pembuatan generator terdiri dari 2 bagian yaitu pembuatan rotor dan stator.Stator terdiri dari beberapa coil atau gulungan dari kawat tembaga yang dilapisi oleh bahan isolator. Jumlah gulungan menentukan tegangan yang bisa dikeluarkan oleh generator tersebut. Stator yang direncanakan terdiri dari 18 gulungan yang masing-masing gulungan terdiri atas 90 lilitan dan tiap 6 gulungan digabung secara seri sehingga didapat 3 fasa tegangan. Kemudian gulungan tersebut dicetak dalam

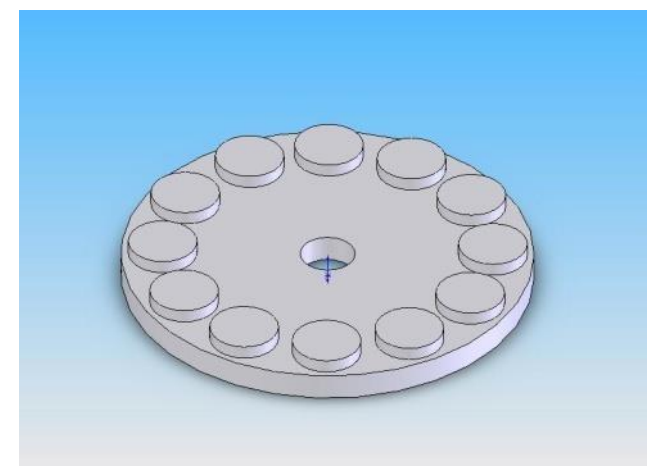

Gambar 8. Desain rotor cetakan resin sehingga membentuk suatu piringan.

Rotor terbuat dari besi yang ditempatkan magnet permanen $(\mathrm{NdFeB})$ pada permukaannya sejumlah 24 buah. Pada generator ini terdapat 2 buah rotor yang mengapit stator dengan polaritas medan magnet yang berlawanan sehingga fluks magnet yang melewati gulungan bisa diperkuat. Antara 2 rotor tersebut disambungkan dengan poros yang kemudian poros inilah yang diputar oleh tenaga angin.

\section{HASIL DAN PEMBAHASAN}

Tipe generator yang telah dibuat adalah output tegangannya berupa tegangan AC 3 fasa. Dari output ini kemudian dilakukan penggabungan fasa dengan model Star lalu dilakukan pengubahan menjadi tegangan DC dengan menggunakan sistem penyearah gelombang penuh melalui 6 dioda. Output tegangan DC ini yang nantinya akan masuk ke rangkaian kontrol untuk proses pengisian baterai pada saat generator ini dipakai sebagai generator turbin angin. 
Model rotor yang telah dibuat pada rancang bangun generator tipe AFPMG, terdiri dari susunan magnet permanen berjumlah 24 buah. Magnet permanen yang dipakai ialah jenis magnet Neodymium grade N35 yang mempunyai kekuatan induksi magnetik maksimum 12.500 Gauss.
Bentuk gelombang tegangan output generator ditunjukkan pada Gambar 9 yang berbentuk sinusoidal. Data ini diambil pada kondisi open circuit saat kecepatan generator $150 \mathrm{rpm}$ pada salah satu fasa.

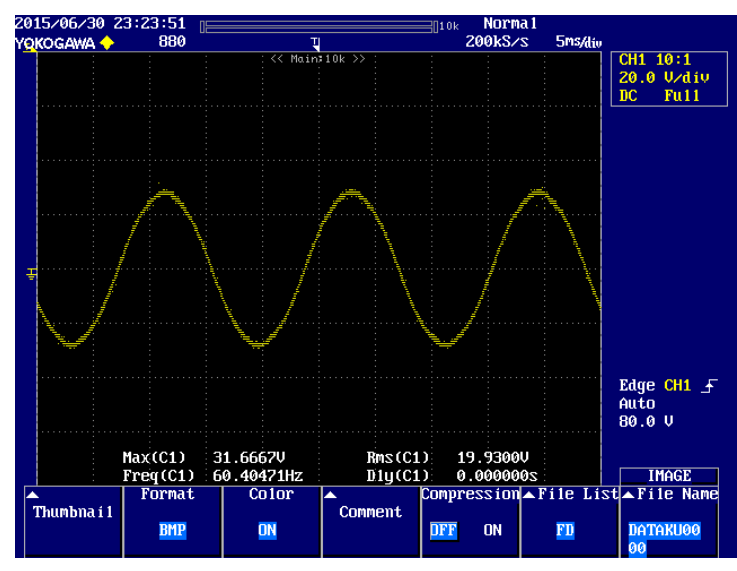

Gambar 9. Tegangan AC satu fasa output generator

Tahapan pengujian generator yang telah dilakukan ialah pengujian generator pada rangkaian terbuka (open circuit), dan pengujian generator dengan pembebanan (close circuit).

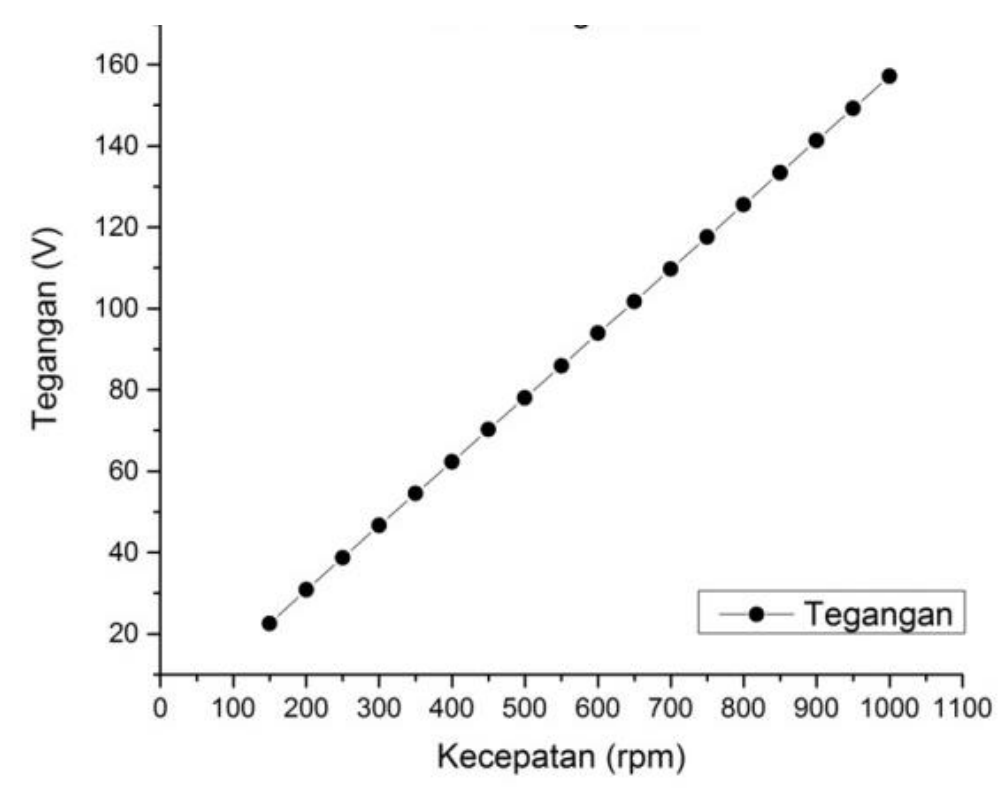

Gambar 10. Hasil pengukuran tegangan pada rangkaian terbuka 
Pengujian ini dilakukan untuk mengetahui karakteristik tegangan output generator pada rangkaian terbuka. Tegangan yang diukur ialah tegangan yang telah disearahkan oleh dioda. Pengukuran dilakukan pada kecepatan awal $150 \mathrm{rpm}$ dengan asumsi bahwa pada kondisi kecepatan angin $3 \mathrm{~m} / \mathrm{s}$ maka kecepatan putaran baling-baling dan poros generator adalah $200 \mathrm{rpm}$. Hal ini diperoleh dari karakteristik baling-baling turbin sebagai berikut:

Panjang baling $(\mathrm{r}) \quad: 1 \mathrm{~m}$, keliling $=2 \pi \mathrm{r}$ $=2 \times 3,14 \times 1=6,28 \mathrm{~m}$

TSR $: 7$

Kecepatan (v) ujung bilah $=7 \times$ kecepatan angin $=7 \times 3 \mathrm{~m} / \mathrm{s}=21 \mathrm{~m} / \mathrm{s}$

Jadi kecepatan putar $(\mathrm{rps})=\mathrm{v}:$ keliling $=21$ : $6,28=3,34 \mathrm{rps}=200,4 \mathrm{rpm}$

Pengukuran daya output dilakukan dengan pembebanan pada output tegangan generator dengan menggunakan 3 variasi nilai resistansi beban. Pengujian awal menggunakan bola lampu yang memiliki resistansi $83 \mathrm{ohm}$, lalu dilanjutkan dengan menambahkan beban bola lampu secara paralel sehingga memiliki resistansi $43 \mathrm{ohm}$, dan pengujian ketiga menggunakan penambahan jumlah bola lampu dengan resistansi total 23 ohm. Dari hasil pengukuran daya yang telah dilakukan, didapatkan bahwa semakin kecil nilai resistansi dari beban, maka nilai daya yang dihasilkan semakin besar pada kecepatan putaran yang sama. Hasil pengukuran menunjukkan bahwa generator yang telah dibuat mampu menghasilkan daya $98 \mathrm{~W}$ pada kecepatan 1000 rpm dengan disambungkan beban dengan nilai resistansi $23 \mathrm{ohm}$.

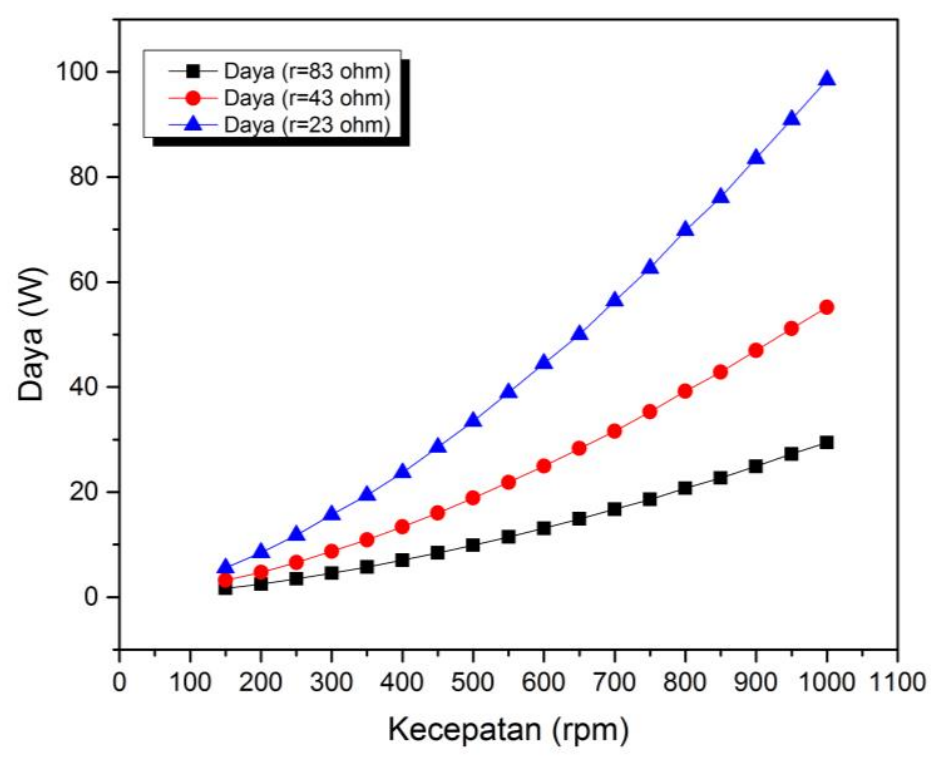

Gambar 11. Hasil pengukuran daya output dengan variasi beban

\section{KESIMPULAN}

Sudah dibuat generator turbin angin yang dapat menghasilkan tegangan pada rentang kecepatan angin $3-6 \mathrm{~m} / \mathrm{s}$. Dari hasil pembuatan generator, dapat disimpulkan sebagai berikut :

1) Pada kecepatan $3 \mathrm{~m} / \mathrm{s}(200,4 \mathrm{rpm})$ menghasilkan tegangan 30,8 Volt, 
pada kecepatan $6 \mathrm{~m} / \mathrm{s}(401,2 \mathrm{rpm})$ menghasilkan tegangan 62,3 Volt.

2) Daya output generator yang dihasilkan pada beban dengan resistansi $23 \mathrm{ohm}$ adalah $15,7 \mathrm{~W}$ pada $300 \mathrm{rpm}$ dan $98,5 \mathrm{~W}$ pada $1.000 \mathrm{rpm}$. Nilai ini diukur dari output generator secara langsung tanpa melalui rangkaian kontrol.

\section{REFERENSI}

Dae-Won Chung, Yong-Min You,2014. Design and Performance Analysis of Coreless Axial-Flux Permanent-Magnet Generator for Small Wind Turbines. Journal of Magnetics. Vol. 19(3),pp. 273-281

Dalimi, "Energy Outlook \& Statistics", 2001.Universitas Indonesia

Daryanto, Y., 2007. Kajian Potensi Angin Untuk Pembangkit Listrik Tenaga Bayu. Balai PPTAGG - UPT-LAGG

Dipl. Kulturwirt, Gunnar Braun. The Potential of Wind Power as a Renewable Energy Source for Indonesia. July 2002. University of Passau, Department of Southeast Asian Studies

Erich Hau, 2005, Wind Turbines: Fundamentals, Technologies, Application, Economics $2^{\text {nd }}$ edition. Springer.

F. J. Gieras, R. J. Wang, and M. J. Kamper, 2008.Axial Flux Permanent Magnet Brushless Machines, Springer, $2^{\text {nd }}$ edition, 304

Gustave Paul Corten, Faculteit Natuur- en Sterrenkunde van de Universiteit

Utrecht, 8 September 1968, ISBN 90-3932582-0 , NUGI 837

Henrik Stiesdal, Hugh Piggott, Bonus Energy A/S. Autumn 1999, www.bonus.dk

Khan, N.I., Iqbal, M.T., Hinchey, Michael, dan Masek, Vlastimil. 2009. Performance of Savonius Rotor As A Water Current Turbine. Journal of Ocean Technology. Vol. 4, No. 2, pp. 71-83 